\title{
PAKISTAN
}

\section{Media, politics and the threats to journalists in Pakistan}

\begin{abstract}
This article examines how the fundamental right of freedom of expression for news media in Pakistan continues to be threatened both by the government and conflicting parties, an issue that is compounded by the threat to the journalists' safety and survival. Giving examples of three Pakistani journalists who lost their lives after their investigations during the America's so called 'War on Terror', the article gives an account of the nature of the dangers and threats that are faced by the journalists in Pakistan who report on armed political conflicts. Drawing on the experiences of five other journalists, who were interviewed during research visits to Pakistan in 2012 and 2014, the author also reflects on the role of journalists in the light of the social responsibility theory and explores some of the factors that contribute towards making conflict reporting a dangerous business in Pakistan.
\end{abstract}

Keywords: conflict reporting, conflict resolution, Fourth Estate, freedom of expression, media freedom, Pakistan, social responsibility, 'trust bonus', watchdog

\section{RUKHSANA ASLAM}

Pacific Media Centre, Auckland University of Technology

OURNALISM is considered to produce the first draft of history (Tomalin, 1969). Journalists follow the oral tradition of storytelling, but their 'stories' are the reporting of facts using their skills of observation, description and writing. 'To grow up in the profession was to discover a trove of impressions, claims, images and declarations' (Lynch, 2013, p. 2). The ideals of the journalists' role in society have been to inform and educate the public. They are the watchdogs in society, guarding the interests of the people, fulfilling their socially responsible role in society (Robie, 2004; 2014).

Journalists are often referred to as the Fourth Estate and the guardians of public trust. Indeed Siebert et al (1963) argued that journalists have a social responsibility to criticise those in power on behalf of the peoples and societies, more or less serving as their watchdogs (Siebert et al, 1963; Curran, 2011). 
POLITICAL JOURNALISM IN THE ASIA-PACIFIC

Article 3 of the 1978 UNESCO Declaration states that 'the mass media have an important contribution to make to the strengthening of peace and international understanding and in countering racialism, apartheid and incitement to war' (UNESCO 1978, p. 1). The social responsibility of journalism, in Nordenstreng's opinion, calls for initiatives 'to systematically monitor what the media tell about the world with a view to improving media performance and contributing to media ethics' (2001, p. 1).

Moral responsibility to society, it thus follows, is an important obligation of journalists. According to Kempf, it is their goal. However, 'it is not an external goal imposed on journalism from outside... [but] results directly from the role assigned to journalism in democratic societies (Kempf, 2007). In return, Kempf argues, it rewards the journalists with the 'trust bonus' that the public gives to them; the faith that the journalists would 'comfort the afflicted, and afflict the comfortable'; that they would 'scrutinise the powerful on behalf of the powerless'; that they would give 'voice to the voiceless'. The public trust bonus is thus collective in its application. It implies 'the willingness' of the people to believe in the credibility of journalists, to give them access to information and to share their thoughts and experiences. The watchdog role of journalists owes a great deal to that 'trust bonus' (Kempf, 2007).

But what happens if the equation is reversed? What happens when this 'trust bonus' is withdrawn, especially if it is a conflict that is as much about politics as about religious beliefs and ideologies; when journalists are not given access to the conflict; when no information is available to them about the human suffering; when there is no opportunity to capture images and when all the parties in the conflict, including the local community, are not willing to trust them? The case in point: Pakistan's tribal areas.

\section{Pakistani journalists and the war in tribal areas}

Kabir building is located in the heart of Quetta - the capital city of Balochistan, which is one of the four provinces of Pakistan and closest to the tribal borders of Afghanistan where the so-called US 'War on Terror' has been taking place since 2005. Kabir building is known as 'Quetta's Fleet Street where national and international media offices jostle for space in the 1950s building compound' and discuss their stories (Intermedia Pakistan, 2011, p. 3). Most of the conversation revolves around which stories should be 'filed' and which should be 'killed'. The test question is always the same: 'is it worth your life?' (p. 3)

The irony - and the gravity - of the situation is not lost to anyone who believes in the media's right of the freedom of expression. Not even to those living in Pakistan, a thickly populated country that has survived three military regimes, two dictators and three wars with neighbouring India within its short life of 68 years. Since 2005, Balochistan has been the military base for the US forces, to launch drone attacks in the so-called 'War on Terror' against the Taliban after 9/11. 
The long porous border with Afghanistan has meant an influx of Taliban leadership into the Pakistani tribal areas bordering in the region (Mir, 2009). The War on Terror was also fought in Pakistan's other Federally Administered Tribal Areas (FATA) from 2005 till 2012. These tribal areas lie in the remote region of the North-West of Pakistan also bordering Afghanistan.

The special report Press in stress: Media under threat in Balochistan was compiled by Intermedia Pakistan in 2012 and contains the findings of the 'Assessment Mission' that went to Balochistan in 2011 to determine the state of media in the country. It was supported by the Pakistan Journalists Safety Fund (PJSF), an initiative run by an independent Steering Committee of Pakistan's renowned journalists and human rights activists, and managed by the Pakistan Union of Journalists and non-governmental

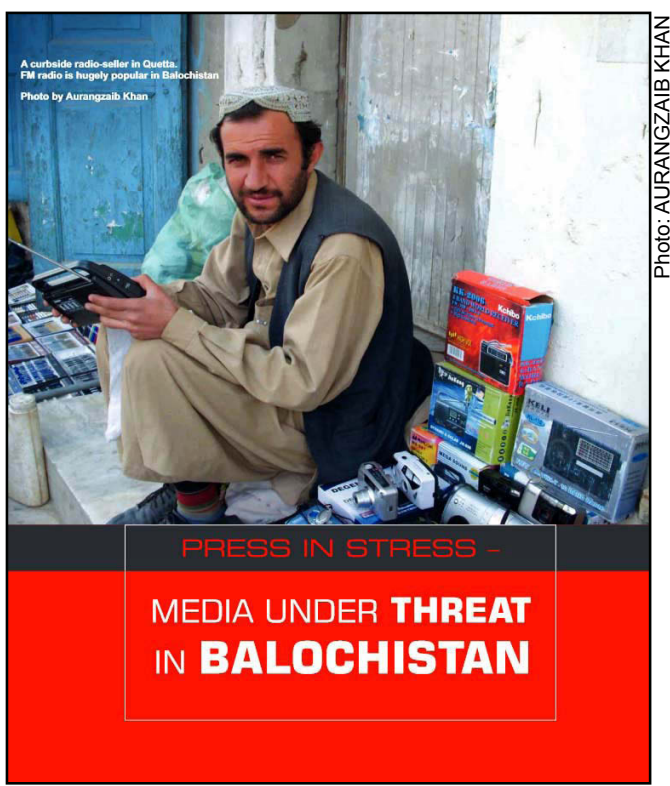

Figure 1: The Press in Stress report in 2012. Shown in the cover image is a curbside radio-seller in Quetta. FM radio is hugely popular in Balochistan. organisation Intermedia Pakistan.

The report is a revealing example of how fragile and insecure are journalists' lives when reporting on the political imbroglio in Balochistan. It notes that approximately 76 journalists in Pakistan were killed for doing their job and investigating events between January 2000 and December 2011 alone, making Pakistan one of the most dangerous countries for journalists in the world at the time. Reporting in Balochistan has become 'the toughest beat one can ask for'.

Torn between duty, ambition - the relentless drive, that is breaking news, to keep a job or hunger for scoop — and the anxiety to stay safe, journalists in Balochistan are watchful of both news and the consequences of reporting it. (Intermedia Pakistan, 2012, p. 3)

Reporting on the US 'War on Terror' fought in Balochistan and the FATA has cost many Pakistan journalists their lives. But it also provides a 'unique case' in the analysis of journalists' role in an armed conflict led by the US forces on Pakistan's soil. Despite Pakistan being the epicentre of the conflict, there is no access for local or foreign journalists to cover the conflict. The foreign journalists are looked upon as spies and the local journalists not only face death every day, but are also looked upon with mistrust by the government as well as the local community (Aslam, 2010). The local Taliban's 
POLITICAL JOURNALISM IN THE ASIA-PACIFIC

approach towards the media is even worse. They are hostile to the presence of any outside media person, considering them all 'Western spies' (Dietz, 2006).

Some cases are discussed below to demonstrate how journalistic investigations into stories led to journalists being harassed, kidnapped, tortured and killed:

\section{Hayatullah Khan}

A young journalist in his 30s, Hayatullah Khan was a reporter for the English language daily The Nation and the Urdu newspaper, Ausaf; he was also the general secretary of the Tribal Union of Journalists (TUJ) and had been covering the US-led 'drone attacks' in Waziristan since the beginning. Hayatullah was kidnapped by gunmen in January 2006 and found shot in North Waziristan six months later on 16 June 2006. His family and many others believe he was kidnapped and detained by the security agencies for his reporting on US military action in tribal areas. According to Aamer Ahmed Khan, who reported his death on BBC News Karachi (Mystery of murdered tribal journalist', BBC Online News, Karachi, June 19, 2006). Hayatullah Khan was the first journalist to show the remains of the drone after one attack, in the midst of the US denial of drone attacks on the tribal village

The report said the Pakistan government officials were 'furious' because of his 'independent reporting'. 'Mr Khan went missing after reporting that al-Qaeda suspect Abu Hamza Rabia had been killed in a US air strike - and not in an accidental explosion while making a bomb, as claimed by Pakistani authorities','it said.

Mazhar Abbas, secretary general of Pakistan's largest journalist union, pointed at the government as 'the prime accused' in Khan's report. 'Unless it can pinpoint and arrest Hayatullah's murderers, it may be impossible for the government to shake off the allegations of being guilty of killing a journalist,' he was quoted as saying in the report.

Dietz, Asia programme coordinator of Committee to Protect Journalists (CPJ) - a New York-based independent, non-profit organisation that promotes press freedom worldwide - led an inquiry mission to Pakistan in July 2006 (www.cpj.org). His report, 'The last Story: Hayatullah Khan' (Dietz, 2006), said that the dead journalist was no stranger to trouble in Pakistan's troubled tribal areas. 'In 2002, US forces in Afghanistan's Paktika province detained Khan for four days. Over the years, he was threatened by virtually every regional faction: Pakistan's powerful Inter-Services Intelligence division (ISI), the military, the Taliban, and al-Qaeda,' he wrote.

Whatever role, if any, the government played in Khan's killing, it appeared to engage in a cruel misinformation campaign during his six-month disappearance. As Khan's family careened between government sources in search of information, the official account morphed from one month to the next: Khan was in government custody, soon to be released; Khan had been abducted by 'miscreants'; he had been taken by Waziristan mujahedeen; he had been flown to the military base at Rawalpindi and then detained in Kohat air base... a regional government agent, summoned family

180 PACIFIC JOURNALISM REVIEW 21(1) 2015 
members on May 15 to say that the journalist was at the US-run Bagram air base in Afghanistan. (Dietz, 2006)

'Of the eight journalists murdered in Pakistan since 2002', Dietz also reported, 'only the case of the American, Daniel Pearl, has been investigated to any result or degree of competence'.

Chandran (2006) argues in his article that while the murder of Daniel Pearl (South Asia bureau chief of the Wall Street Journal) at the hands of Taliban in February 2002 attracted much attention and occupied the headlines, the Taliban ban on media in the region had gone largely unnoticed. For instance, two journalists working for the Frontier Post and Khyber TV, Amir Nawab Khan and Allah Noor Wazir, were killed in Wana town by the militants in February 2005. Some were luckier: Dilawar Khan Wazir, a Wana-based journalist working with BBC World Service, was warned with a bomb in his compound after he participated in a Voice of America radio programme in December 2005. 'Militants have repeatedly issued threats against any adverse reports, both in the electronic and print media,' Chandran (2006) wrote online.

\section{Syed Saleem Shahzad}

An Islamabad-based investigative journalist, Syed Saleem Shahzad, 40, wrote for leading European and Asian media. He worked for the Italian news agency Adnkronos and was the bureau chief of Asia Times Online, Hong Kong. He reported on the naval base attack on 22 May 2011 that took 17 hours to repel. The Taliban had claimed responsibility, saying the attack was carried out to avenge the US killing of Osama bin Laden in Pakistan (Waraich, 2011).

According to the news report, Shahzad's last piece was an investigative report that al-Qaeda had carried out the attack on Pakistan's naval air base on 22 May 2011 to avenge the arrest of naval officials arrested on suspicion of having Al-Qaeda links (Times, 31 May 2011). Shahzad had alleged that the attack was facilitated by someone in uniform. There had been rumours for months about some navy personnel picked up by intelligence agencies for links to jihadi groups, but the veil of secrecy was tight and media reports had not got very far on the details.

Shahzad went missing the next day after he left his home in the capital city Islamabad to take part in a television talk show, but never arrived. His body was found two days later about $150 \mathrm{~km}$ southeast of Islamabad. Police said it bore marks of torture.

The kidnapping and brutal murder of Shahzad created a furore in the national and international news media. The news report on Dawn.com, 3 June 2011 termed the incident 'the perennial squeeze on the truth' and warned that 'burying the truth and journalists like Saleem Shahzad is [not] making Pakistan any safer or stronger' (www.dawn.com, 2011; also see Saleem, 2011).

The Guardian in a report published on 13 June 2011 said that 'chasing the truth' was 
POLITICAL JOURNALISM IN THE ASIA-PACIFIC

a 'perilous business' in the myriad politics in Pakistan and that the country had become 'the world's deadliest beat for journalists'. The Times published on 31 May 2011 that the disappearance of Shahzad was 'a reminder of the multiple hazards faced by journalists working in Pakistan.' Asia Times Online, for which Shahzad worked, published a report 'Who killed Syed Saleem Shahzad?' on 4 June 2011 saying:

Whoever is responsible for Shahzad's barbaric murder, one thing is for sure - he will not be the last journalist to have sacrificed his life for uncovering the truth, as there are many more newsmen in Pakistan who firmly believe that the 'truth' remains superior to the so-called 'national interest'.

\section{Assassination attempts}

On World Press Freedom Day this year, the Intermedia Pakistan, a media-related NGO, launched its annual report, State of Media in Pakistan 2014, giving an analysis of key developments and trends in Pakistani media covering the period 3 May 2013 to 3 May 2014. In its executive summary, it reported the 'targeted killings of five journalists and three media workers'; 'assassination attempts against senior journalists including Hamid Mir and Raza Rumi'; and 'the issuance of a fatwa by the proscribed Tehrik-e-Taliban Pakistan (TTP) that formally declared media a target' (Intermedia Pakistan, 2014, p. 5).

According to the report (pp. 8-9), on 19 April 2014 prominent private television channel Geo TV anchor Hamid Mir, of the popular current affairs programme Capital Talk, was shot in his car near the airport in Karachi minutes after he landed and made his way to his office. Unidentified gunmen in a car and motorcycle tailed him before opening fire, and continued to fire as the vehicle carrying Mir sped away to safety. He sustained six serious gunshot wounds, but survived after being rushed to hospital. Hamid Mir's brother, Amir Mir, himself an investigative journalist of repute, blamed the Inter-Services Intelligence (ISI) for the attack minutes after it occurred on live TV. Hamid Mir himself had declared in his talk show that if ever he was killed, the government's intelligence agencies would be responsible. He had done it as a precautionary measure against possible attempts on his life. Almost years previously, Hamid Mir had narrowly escaped a car bomb planted by the Taliban in November 2012 as they were 'angered over his and other journalists' positive reportage of school girl campaigner Malala Yusufzai' (who received the 2014 Nobel peace prize), says the Intermedia report 2014.

The report also gave an account of journalist and writer Raza Rumi, who on 28 March 2014 narrowly escaped an assassination attempt. His driver Muhammad Mustafa was killed and a guard sustained grave injuries. Unidentified armed men opened fire on his car as Rumi, a news show anchor from Express News TV channel, was returning home after hosting his nightly current affairs show in Lahore (Punjab province). Police recovered 11 bullet shells from the car. 'The car was sprayed with several bullets and

Rumi was able to save his life by ducking between seats in the vehicle's rear' (Intermedia Pakistan, 2014, p. 8).

182 PACIFIC JOURNALISM REVIEW 21(1) 2015 
In an article, 'Pakistan deadliest place to be a journalist' published online on 13 June 2011, The Guardian correspondent Dulcan Walsh, reported that Umar Cheema, another senior correspondent for Pakistan's English language daily The News, was abducted from Islamabad in September 2010. 'Bundled into a jeep and blindfolded, he was taken to a safe house where he says he was stripped, beaten with a leather strap and threatened with rape. After seven hours he was dumped on a road in rural Punjab.'

'The causes of these deaths are as varied as Pakistan's myriad conflicts', declared The Guardian in the same report. 'Some are caught in suicide blasts; others targeted by Taliban militants or Baloch insurgents. In Karachi, several reporters have been gunned down as part of the city's vicious political wars'. The Intermedia's report (2014, p. 6-7) also gives a detailed account of how the threat to journalists has surged from tribal areas to include other political conflicts. On 21 August 2013, Abdul Razik Baloch, a subeditor for Daily Tawar, was found tortured to death in Karachi where he was based for his reporting on the provinces' turbulent political events. On 11 October 2013, Ayub Khattak, working as a reporter of the Karak Times in Karak, was shot dead outside his residence. 'He appears to have been killed for reporting crimes, especially the sale of drugs in his city', the report says. On 1 January 2014, reporter Shan Dahar, working for Abtak TV channel in his hometown of Larkana, was shot in the neck and later died in the hospital. The report cited his employers as saying that he had been receiving threats for reporting 'on the sale of spurious and expired medicine at hospitals and medical stores in Larkana' (p. 6). On 17 January 2014, unknown gunmen on motorcycles shot dead three media workers of the Express media group in Karachi. Banned Tehreek-e-Taliban (the Taliban movement) Pakistan claimed responsibility for the attack. Technician Waqas Aziz Khan, driver Khalid Khan and security guard Ashraf Arain were killed on the spot as they sat in the Express TV DSNG van. Reporter Bakhtaj Ali of the weekly Manzar-e-Aam was kidnapped by unknown people on 28 January 2014 after receiving threatening calls for his reporting. His beheaded body bearing severe torture marks was found on 30 January 2014 in Mardan. On 2 March 2014, Ayub Tanoli, photographer for Reuters news agency and reporter for dailies Mahasib and Shumal was shot in the neck in his hometown of Abbottabad (Khyber Pakhtunkhwa province) by unidentified gunmen. He died on March 3, 2014. According to the Pakistan Federal Union of Journalists (PFUJ) and local Abbottabad Union of Journalists (AUJ), he was under threat for his reporting and had been provided police protection for two months before he was killed.

These examples highlight the magnitude of the problems facing Pakistani journalists engaged in conflict reporting in a situation like this: when they have no access to the conflict; when no information is available to them about the human access to the conflict; when no information is available to them about human suffering; when there is no opportunity to capture images and when all the parties in the conflict, including the local community, are not willing to trust them. 
POLITICAL JOURNALISM IN THE ASIA-PACIFIC

\section{Factors contributing to the threat to journalists in Pakistan}

This section of the article discusses the various factors that contribute to the situation prevalent in Pakistan's case in the light of the media's role in reporting conflict. The arguments are based on the author's doctoral research on the subject, including the interviews conducted with five Pakistan journalists during her visits to Pakistan in 2012 and 2014 (see Aslam, 2014).

\section{Media and conflict}

Conflicts are 'a central part' of human lives (Hamelink, 2011, p. 11) and journalists 'an active part of any conflict' (Tehranian, 2007, p. 2). The power-play between the government and the opposition as manifested in the conflicts is watched, analysed and reported by the journalists. The government's role is to establish the 'authoritative allocation of values for a society' (Easton, 1953; cited in Isaak, 1975, p. 19). On the other hand, the journalists in their watchdog role question these values and the methods employed by the government. The tension between the two sides manifests when each tries to claim and dominate the public sphere of communication, the media space (Hackett, 2007).

According to Castells, the 'historic shift of the public sphere from the institutional realm to [a] new communication space' has made media the platform for social dialogue and power play (Castells, 2007, p. 238). Media have become 'the social space where power is decided'; he argues (p. 238). But news nowadays is not only about power, money or politics; it is also about 'entertainment' (Harcup \& O’Neil, 2001). The advent of the digital revolution and new media technologies has made news more 'entertaining, interactive and instantaneous' (Aslam, 2010, p. 346). It also gives people 'unprecedented access to global events, with immediate and detailed reporting of war'. In a paradox, it has also became the tool for state propaganda; a means 'to inculcate and defend the economic, social and political agenda of privileged groups that dominate the domestic society and the state' (Herman \& Chomsky, 2002, p. 298).

The media assume 'a central role in international affairs' because 'citizens are dependent on media to provide timely, credible information of distant events' (Ross, 2007, p. 54). And journalists act as the communication agents to provide this information. Communication itself 'is a crucial determinant in conflict and conflict resolution: it creates consciousness of, and attentiveness to, the other' (Peleg, 2007, p. 26). The 'information failures' of the media in providing timely and credible information can become a 'primary contributor' in escalating the conflict (Lake \& Rothchild, 1996, p. 73). Such failures occur when the media constructs and reinforces a simplistic or negative portrayal of those representing the other side (Hofman, 1972; Ibrahim, 1972).

'Decades of study of the role of media in ongoing conflicts suggests that media rarely report conflict neutrally', argues Ross (2007, p. 57). In her study on deconstructing conflict reporting, she points out several factors that contribute to the contemporary reporting of conflicts: such as the government pressures, political influences, propaganda mechanism,

184 PACIFIC JOURNALISM REVIEW 21(1) 2015 
foreign policy issues, commercial considerations, structural constraints, political cultures, norms and traditions of societies and nationalistic emotions. Under these influences, the media frame the news on conflict in ways which serve the hidden or prominent interests of the various players in the conflict (Ross, 2007; Herman \& Chomsky, 2002). For instance, after the Gulf War of 1991, many Western journalists claimed they had been duped by the US-led forces (Keeble, 2010). Several reporters gave accounts of how they - despite their ideals of professional objectivity and social responsibility-became obsessed with the military jargon surrounding the sophisticated weaponry. 'Iraqi civilians were reduced to 'targets' and the night air raids were described as 'fireworks'. The horror of the mass slaughter of Iraqi soldiers and citizens lay hidden behind claims of 'heroic victory' (Aslam, 2010, p. 336).

\section{Freedom of expression}

Pakistan's constitution grants the people and the media freedom of speech and expression. The Article 19 of the 1973 Constitution declares:

Every citizen shall have the right to freedom of speech and expression, and there shall be freedom of the press, subject to any reasonable restrictions imposed by law in the interest of the glory of Islam or the integrity, security, or defense of Pakistan or any part thereof, friendly relations with foreign states, public order, decency or morality, or in relation to contempt of court, commission of or incitement to an offense. (Article 19, 1973)

It is apparent under the constitution that while every citizen has the right to freedom of speech and expression and there is freedom of the press. However that 'freedom' is conditional to 'any reasonable restrictions imposed by law' without making clear what is meant by the phrase 'reasonable restrictions' (Nizami, 2013). The very fact that such conditions are 'imposed by law' renders them questionable. The only further explanation given in the Article is that these restrictions can be forced 'in the interest of the glory of Islam or the integrity, security or defence of Pakistan or any part thereof, friendly relations with foreign States, public order, decency or morality, or in relation to contempt of court, commission of or incitement to an offence' - terms and phrases that are neither explained nor defined. Their meaning and application can be subjective and relative to individual interpretation or interests.

The same limitation applies to the journalist's right to information-Article 19(A) of the Constitution of Pakistan grants every citizen 'the right to have access to information in all matters of public importance subject to regulation and reasonable restrictions imposed by law.' There is little doubt how limited the scope for freedom of expression is for the local journalists and how great the risk of being manipulated by the political government and its agencies. 
POLITICAL JOURNALISM IN THE ASIA-PACIFIC

Pakistan's media have undergone massive change over the past decade. Until 2004, there was only one state-owned television channel, one national radio station and five regional radio stations. Since former president Pervez Musharraf liberalised the television sector in 2004, the number of TV news channels has increased to dozens. The boom has created thousands of jobs and fostered a vigorous culture of debate (The Guardian, 2011). But there have also been negatives.

Reporting can be reckless, with some channels spreading lurid conspiracy theories in pursuit of ratings. Military and civilians leaders use the media to manipulate public opinion through bribery, intimidation or coercion. And clear 'red lines' about what is permissible still exist. (Walsh, 2011)

In the case of the assassination attempt on Hamid Mir's life mentioned above, the allegations against ISI turned into a 'war of words' between Geo TV and the military, according to the Intermedia's new report Annual State of Media in Pakistan 2014 (p. 9). The military asserted that privately owned Geo TV, by making allegations against ISI, had been 'unpatriotic' and 'treasonous.' A reference was also filed by the Ministry of Defence, on request by the security agencies, to Pakistan Electronic Media Regulatory Authority (PEMRA) 'to ban Geo TV for bringing the armed forces in disrepute through unsubstantiated allegations'. A three-member Judicial Commission was established to probe into the attack on Hamid Mir and 'to recommend measures to combat impunity against journalists in Pakistan,' the report adds (p. 9). The media reports on Hayatullah Khan's disappearance also mentioned the fact that the government and the military did not like his independent reporting.

What happened to the journalists discussed in the above section is a reflection of the direst consequences of the conditions imposed in Article 19 and 19(A) which make investigative reporting against the 'armed forces' or 'the friendly states' or the so-called custodians of the 'glory of Islam' so dangerous for the journalists. It is what provides justification to all the conflicting sides to 'target journalists arbitrarily and with brutality' (Times, 31 May 2011).

\section{Propaganda, lies and secrecy}

Propaganda and secrecy are the hallmarks of all conflicts, which makes it difficult for the journalists to seek truth. Lynch \& Galtung (2010) argue that news coverage in most conflicts is fed on 'embedded journalism' and the 'communiqués from the top military command' (Lynch \& Galtung, 2010, p. 17). In an age of globalisation, new media technologies and visual images, 'we are immersed in war propaganda; our media relations, our very medialised existence perhaps, is saturated in it' (Lynch, 2010, p. 81). Jowett and O'Donnell (1999) define propaganda as 'the deliberate and systematic attempt to shape perceptions, manipulate cognitions and direct behaviour to achieve a response

186 PACIFIC JOURNALISM REVIEW 21(1) 2015 
that furthers the desired intent of the propagandist' (Jowett \& O'Donnell, 1999, p. 6). 'News is the ideal vehicle for this because it weaves images and snippets of information into what Gaye Tuchman calls 'a web of facticity...[i.e.] to flesh out any one supposed fact, one amasses a host of supposed facts that, when taken together, present themselves as both individually and collectively self-validating' (Tuchman, 1978, as cited in Lynch, 2010 , p. 72). Journalists' investigations, it means, have to find a way through information shrouded in propaganda, misinformation and secrecy. Add to it the slippery road of the freedom of expression and speech as outlined in the Article 19 and 19(A) of Pakistan's Constitution 1973, and the stories of Hayatullah Khan, Saleem Shahzad, Hamid Mir and the others do not come as a surprise.

The initial accounts of media-related NGOs, like Internews Pakistan, in June 2006 showed that within the first six months of the War on Terror, at least 20 journalists in the tribal areas were killed, kidnapped, arrested, tortured or threatened by the local administration, the law enforcement agencies and the Taliban. The Pakistan Press Freedom Report (2007) added that 'most journalists in tribal areas have either been forced to give up their profession or leave their home town. The few that remain, limit their coverage to innocuous topics such as school functions and activities of administration officers.'

Since then, the only source of information left in the tribal areas is provided by the Inter Services Public Relations (ISPR) which is the army's official agency (Aslam, 2010). Its news credibility remains 'questionable as most of it is written in and disseminated not from the conflicted areas but its offices in Islamabad' (p. 348).

ISPR claimed dozens of Taliban leaders had been killed yet not a single photograph was released to the press in the first five years of the conflict. It claimed that the tribal area of Swat was cleared of all Taliban elements yet the Radio News Network reported on 21 July 2009 that the Taliban were running an FM radio station-just days after the internally displaced people (IDPs) from the valley were allowed to go back to their homes. Before the military operation in Swat began in April 2009, an estimated 88 FM radio station were estimated to be operating illegally in the area, mostly by the Taliban (Aslam, 2010, p. 348).

The reports of the Taliban leader Baitullah Mehsud being killed in the drone attacks came in August 2009. Lanche (2009), a research intern at the Institute of Peace and Conflict Studies (IPCS), wrote in an article that it was a fact that a missile strike had destroyed Taliban leader Baitullah Mehsud's father-in-law's house in Zanghora, South Waziristan, on 5 August 2009. But ironically 'no one knows for sure if the Tehrik-i-Taliban Pakistan (TTP) chief was either killed or injured in the blast,' he wrote. 'Since then, various contradictory statements have been made by US officials, Pakistani intelligence and Taliban commanders to confirm or invalidate Mehsud's death.' The US media reported in the affirmative, followed by the confirmation by Pakistan's foreign office official and the Interior Minister but denied by the Taliban. Lanche concludes: 
POLITICAL JOURNALISM IN THE ASIA-PACIFIC

... neither the government nor the Taliban have been able to produce any material evidence that TTP's charismatic leader is either dead or alive. 'Time will reveal the truth', most Pakistani commentators say. But patience will be required here, for one cannot step [into] South Waziristan to confirm the facts so easily. (Lanche, 2009)

\section{Players and interests}

Also pertinent to the discussion is the issue of the interests and stakes of the involved parties in the conflict. Lynch \& Galtung (2010) argue that there is a tendency to see conflicts as a game between two sides fighting to win the game, ignoring the underlying geo-economic, geo-political and geo-cultural aspects of the conflict. In real-life conflicts, 'there are never only two parties (teams), never only one ball, the field is tilted, not even, and the numerous parties are not necessarily playing the same games with the same balls' (Lynch \& Galtung, 2010, p. 6). 'Some parties are not playing at all, are only around hoping for some spoils to pick up' (p. 6).

In the case of the War on Terror, the game is complex, the players many and the stakes high. Pakistan, with an area of 796,095 sq. km, is an Islamic Republic located in the South of Asia sharing borders with Iran, India, Afghanistan and China. Offering the only gateway to the land locked Central Asian Republic States, Pakistan occupies a geopolitically important location at the crossroads of South Asia, the Middle East and Central Asia (Mohiuddin, 2006). The War on Terror is America's war against the Taliban being fought on Pakistani soil but with equally high stakes for the neighbouring countries India, China and Iran (Mir, 2009). And while the Taliban movement might have roots in Afghanistan, they are equally settled in Pakistan's tribal areas and have even adopted Pakistani citizenship. The people of Pakistan are divided on the issue as to what extent the government should help America wage a war against their own (Mir, 2009).

After almost a decade of the conflict, all journalists the author interviewed in her visits to Pakistan in 2012 and 2014 want to see the conflict in Pakistan end, issues resolved and peace restored. But what version of 'peace', is another matter entirely, says Tanveer Shazad, a freelance photojournalist for AP and Reuters who has covered the conflict extensively over the years. 'Whose version of peace are we talking about? America's? Afghanistan's? Pakistan's? Taliban's? The Tribal Areas'? Or the neighbouring countries?,' he said in an interview with the author. In his opinion, 'each player's definition of peace is linked to their interests'. America would like to see the Taliban eliminated; Pakistan would like to slide back peacefully into America's good books politically and economically; the Taliban want their hegemony in Afghanistan; the tribal areas want the Pakistani and American forces to back off and to regain their independent existence; India prefers to see Pakistan lose its political and economic footing in the region so as to tip the regional balance in its favour; and China sees the conflict as a threat to its economic stakes in Pakistan as well as in the region. 'There are as many versions of peace as are the players and stake holders,' he said (Interview, 7 April 2012).

188 PACIFIC JOURNALISM REVIEW 21(1) 2015 


\section{Training, support and attitudes}

Among other factors discussed in the above section, the Intermedia's special report on Balochistan 2012 acknowledges that the threats and dangers faced by the journalists in Balochistan are compounded because they are 'less qualified, ill-equipped, inexperienced and not trained', especially when there is no organisational support system at any level for them (p. 17). They are learning conflict reporting the hardest way, it says-'by risking their lives' in their efforts to keep the flow of information running, 'uncluttered from the all-round propaganda that permeates the province'. (p. 2)

Unfortunately, the incidents of violence against journalists have become so common that it has created apathy and indifference in newsroom offices also. This is reflected in the story of Ahmed Bilal, the 27-year old cameraman assigned to the TV reporting team to cover Taliban activities along the areas of North and South Waziristan, Khyber Agency and other tribal areas where they have a stronghold. He was kidnapped by the Taliban in 2011, imprisoned for several days and then released. Bilal was one of the few lucky ones to have survived the experience, mainly because he was a local journalist and knew the Taliban's language and customs. But feeling helpless and captive, not knowing how long he would live, admitted Bilal, was nonetheless a harrowing experience for him. When he was released by the Taliban after re-assuring them that he was 'not a spy', there was another surprise waiting for him in his office. 'So when I came back to my office afterwards, they looked at me and said: "Oh, you are back. Good. What's up?", (Interview, April 7, 2012)

Bilal's recount of what he called 'the remarkable apathy' on the part of his colleagues towards him reflects two things about the mindset in the newsrooms in Peshawar. First, that the media organisation takes no responsibility or liability regarding the risk to a journalist's life, property or job. And second, he added, the threats to journalists in the form of kidnappings and killings have become so common that they have become a routine matter - nothing to be worried or excited about.

As the author talked to Bilal (Interview, 2012), he laid out a list of what was lacking in the 'organisational support system' to provide health and safety for journalists when they covered conflict areas in Pakistan. It included no background briefing, no formal training on survival techniques, no additional expenses and no transport from the organisation. In the case of injury, he added, there is no medical or life insurance by the organisation and no disability allowance in terms of financial benefit. According to Bilal, it affects intensely the Pakistani photojournalists and cameramen more who have to rely on either the reporter for his knowledge and experience, or on the party they are travelling with - the armed forces or the tribal people. The training on first-aid was given to them once, said Bilal, 'but it was organised by the Peshawar Press Club and funded by an NGO. No news organisation does it.' In Bilal's own case, there was no post-trauma therapy or care provided to him by his organisation after he came back from his ordeal.

Another senior photojournalist, Abdul Majeed Goraya, who worked with Bilal several 
POLITICAL JOURNALISM IN THE ASIA-PACIFIC

times on assignments, endorsed Bilal's comments. He recalled an incident in which he and his team were shot at by the soldiers at a check-post that borders the tribal Mahmund Agency. They ran for their lives but the driver got shot in his back and was disabled for the rest of his life. 'He got no compensation for getting injured while on duty; rather he lost his job and his savings. In the end, other journalists in the city and members of the press union collected some funds to help him,' he said (Interview, 7 April 2012).

There is also no job security or reward for the journalists for risking their life. 'Most of the time we are on our own when we travel on such assignments. We don't get any money for travel fare, food, lodgings or transport,' Goraya said. 'Sometimes we get reimbursed - for instance if we get good stories and pictures - but not always'. Their incentive is their byline or what gets sold to international news agencies like Reuters, AFP or AP etc.

But Goraya said that this was accepted by many photojournalists. What disturbs them more, in his opinion, was the risk to their equipment in case of breakage, accidents or confiscation by the army or government agencies. 'The first thing that happens when they don't want us to film and take photos is that they break our cameras and recorders. That's the worst part. So the first thing we do on such occasions is hide the equipment,' he said. He conceded that it may seem ironic to worry about one's equipment more than one's life. But the equipment is very expensive, is the personal property of the photographers and not provided by the organisation; hence it is seldom insured. Getting it broken or confiscated can effectively cripple their work and livelihood, he pointed out. Without hopes of an insurance covering it, the loss can be too great for many photojournalists to take lightly.

The only thing that the Pakistani journalists get when they are travelling with the army is the protective jacket. 'But many of us cannot use them,' said Bilal. 'They are the military jackets provided by the American army and easily recognised by the locals and the Taliban. We will be considered a spy and shot before we can say "surrender", he explained albeit laughingly. Moreover, the design of the jackets does not provide an 'adequate cover'. Upward they can protect the chest, 'but what about the rest of the body - the arms, the head, the spine and the legs', said Bilal. 'A bullet in any of these parts can be equally dangerous.'

In Shahzad's opinion, the photojournalists face greater threats and dangers than the reporters and hence have a tougher job to do. 'Reporters have many sources on their hand and can write a story sitting on their desks and getting information on their phone or computer. It is secondary information but a much safer option. But a photojournalist needs to be on the spot where things happen,' he explained.

Moreover, photojournalists need greater presence of mind and energy to make onthe-moment decisions and judgement calls. Sometimes having other people around hinders their creativity. So they work best when they are on their own and, therefore, they are exposed to greater risk to their life and equipment. (Interview, 7 April 2012)

190 PACIFIC JOURNALISM REVIEW 21(1) 2015 
Recalling his own experiences during many assignments while covering the War on Terror in the Swat region, which won him the prize for best coverage in 2011, Shahzad said: 'A picture that is worth a thousand words does not come by itself. Sometimes I had to spend hours working on my own to find a new angle and a new perspective for my pictures.' It was risky and many times he had to rely on his knowledge of the local area and customs to help him out in tricky situations. But it was always 'more satisfying because a good creative picture really does not need a story,' he said (Ibid.).

\section{Improving the situation}

Many media professionals in Pakistan feel that the problems faced by the Pakistani journalists can be solved by providing them with adequate training, organisational support and capacity building. Zahir Shah Shirazi, Bureau Chief of DAWN TV in Peshawar, for instance, believes that journalists are 'part of society and media is a tool.' They can give hope to the people after wars and give voice to their needs and issues, he said in an interview with the author in 2012. 'They need to learn constantly to adapt themselves to the changing situations and therefore must be empowered through organisation's support, better education and professional training.' (Ibid.)

Indeed, the special Intermedia report Press in Stress: Media under threat in Balochistan (2012) recommends a list of measures that ought to be taken to make media in Balochistan 'both professional and safe' (p. 19). They include a broad range of suggestions: some as specific as providing the local journalists professional and safety/survival training courses, better wages, job security and insurance of life and their equipment. The other suggestions are general and pertain to the government's obligation to provide journalists safe and speedy access to information, to initiate media-community dialogue, and to train 'the military and government sources in dealing with media, the media's information needs and the need for independence' (p. 19).

For Pakistani journalist Goraya, the solution to the journalists' problems lies in three words: Access, trust and respect. He says: 'Give the journalist access to the story; trust the journalist enough not to kill him; and give the journalist respect enough not to kill his story' (Interview, 2012). His plea is equally directed to the editors, media organisations, the government and the conflicting parties, who for their own stakes and interests put journalists' lives on line.

Intermedia's new report on the Annual State of Pakistan Media 2014 also gives a detailed account of the Pakistan Coalition on Media Safety (PCOMS), which was set up in March 2013 in Islamabad, Pakistan, by a broad-based group of relevant stakeholders including representative associations of media owners, media workers, working journalists, media development organizations, human rights organizations, civil society groups, parliamentarians and the government, and was reactivated through a Steering Committee in October 2013. The PCOMS was further divided into two sub-committees. One was 'mandated with drafting a set of recommendations on appointment of a special prosecutor 
POLITICAL JOURNALISM IN THE ASIA-PACIFIC

to investigate attacks against media and crimes against journalists' $(2014$, p. 15). The second sub-committee worked 'to consult key media houses and other stakeholders to evolve a set of consensus safety protocols based on best practices and on the peculiar security environment of Pakistan that would be adopted by most major media houses in the country' (p. 15). The result was the comprehensive draft proposal of security policies, protocols and procedures for the journalists, editors and media houses to observe and practice while working in a conflict zone. The overriding principle for everyone was: 'no story is worth your life' (p. 16).

\section{Conclusion}

Journalists are an active part of politics in any country, whether it is in the developed or developing world. In conflicts, the politics becomes more complex, the situation more complicated and information-gathering more difficult. The journalists' right and freedom to seek and speak without fear or threat might be taken for granted in peaceful democracies but in countries like Pakistan where anarchy, strife and disorder reign during a conflict, upholding the journalistic principles of truth and justice is a struggle against the tide. There are recommendations, protocols and advice designed and recommended by the concerned media professional and organisations for the safety and security of the Pakistani journalists in areas of conflict as well as for the media organisations. The problem continues however because they are not implemented, as the discussion above shows.

In the case of Pakistani journalists, it would not be unrealistic to expect that the fear of loss of life, job or property would force them to shun the 'public trust' and digress from their professional path. But the fact that there are journalists still reporting in Pakistan in the political turmoil proves that journalism under threat has become something more than just a profession or a spirited defiance or even battle for survival. It is a commitment, a responsibility and for some, perhaps a quest. Giving journalists what Goraya calls for, i.e. 'access', 'trust' and 'respect', is not more than what they give in return: their lives.

\section{References}

Article 19. (1975). Pakistan Constitution Law 1975. Retrieved from http://pakistanconstitutionlaw. com/article-19-freedom-of-speech-etc/

Aslam, R. (2014). The role of media in conflict: Integrating peace journalism in the journalism curriculum. Unpublished doctoral thesis in the Pacific Media Centre, School of Communication Studies, Auckland University of Technology. Available at http://aut.researchgateway. ac.nz/handle/10292/7908

Aslam, R. (2011a). From hope to challenge. Media Development, WACC, LVVIII(2), 2-8.

Aslam, R. (2011b). Peace journalism: a paradigm shift in traditional media approach. Pacific Journalism Review, 17(1), 113-134.

Aslam, R. (2010). Perspectives on conflict resolution and journalistic training. In R. L. Keeble,

192 PACIFIC JOURNALISM REVIEW 21(1) 2015 
J. Tulloch \& F. Zollman (Eds.), Peace Journalism, war and conflict resolution, (pp. 335-352). London, UK: Peter Lang.

Castells, M. (2007). Communication power and counter-power in the network society. International Journal of Communication, 1, 238-266.

Chandran, S. (2006) Waziristan: Taliban, state and media, Institute of Peace and Conflict Studies, 23 June 2006. Available online at http://www.ipcs.org/articledetails.php?articleNo=2048

Curran, J. (2011). Media and democracy. London, UK: Routledge

Dietz, B. (2006). The last story: Hayatullah Khan. Committee to Protest Journalists, pp. 11-27. Retrieved from http://cpj.org/reports/2006/09/khan.php

Easton, D. (1953). The political system: An inquiry into the state of political science, New York, NY: Knopf.

Hackett, R. A. (2007). Is peace journalism possible? Three frameworks for assessing structure and agency in news media. In D. Shinar \& W. Kempf (Eds.), Peace journalism: The state of the art, (pp. 75-94). Berlin, Germany: Regener.

Hamelink, C. (2011). Media and conflict: escalating evil (media and power). Boulder, CO: Paradigm Publishers

Harcup, T. \& O'Neil, D. (2001). What is news? Galtung and Ruge revisited. Journalism Studies, 2(2), 261-280.

Herman, E. and Chomsky, N. (2002). Manufacturing consent: the political economy of mass media. New York: Pantheon.

Hofman, J.E. (1972). Readiness for social relations between Arabs and Jews in Israel. Journal of Conflict Resolution, 6(2), 241-251.

Ibrahim, S. (1972). Arab images of the United States and the Soviet Union before and after the June War of 1967. Journal of Conflict Resolution, 6(2), 227-240.

Intermedia Pakistan. (2014). Annual state of media in Pakistan 2014. Civic Action Resources \& Freedom Network. Karachi: Adnan Rehmat.

Intermedia Pakistan. (2012). Press in stress: Media under threat in Balochistan. Intermedia Pakistan \& Pakistan Journalists Safety Fund (PJSF). Karachi: Aurangzaib Khan.

Isaak, Alan C. (1975). Scope and methods of political science [Rev. Ed.]. Homewood, IL: Dorsey Press, 19-20.

Jowett, G.S., \& O’Donnell, V. (1999). Power and persuasion. Londonm, UK: Sage.

Keeble, R. L. (2010). Peace journalism as political practice: A new, radical look at the theory. In R. L. Keeble, J. Tulloch \& F. Zollman (Eds.), Peace journalism, war and conflict resolution (pp. 49-68). London, UK: Peter Lang.

Kempf, W. (2007). Peace journalism: a tightrope walk between advocacy journalism and constructive conflict coverage. Conflict \& Communication Online, 6(2). Retrieved from www. cco.regener-online.de

Khan, A. A. (2006, June 19). Mystery of murdered tribal journalist. BBC News, Karachi. [Online] Retrieved from http://news.bbc.co.uk/1/hi/world/south_asia/5096008.stm

Lake, D.A., \& Rothchild, D. (1996). Containing fear: the origins and management of ethnic conflict. International Security, 21(2), 41-75.

Lanche, J. (2009, August 13). Baitullah Mehsud's alleged death: for better or for worse,. Retrieved from www.ipcs.org/article/pakistan/baitullah-mehsuds-alleged-death-for-better-orfor-worse-2942.html

Lynch, J. \& Galtung, J. (2010). Reporting conflict: new directions in peace journalism. Brisbane, Qld: University of Queensland Press.

Lynch, J. (2010). Propaganda, war, peace and the media. In R.L. Keeble, J. Tulloch \& F. Zollman (Eds.), Peace journalism, war and conflict resolution, (pp. 69-83). London, UK: Peter Lang.

PACIFIC JOURNALISM REVIEW 21 (1) 2015193 
POLITICAL JOURNALISM IN THE ASIA-PACIFIC

Lynch, J. (2013). A global standard for reporting conflict. NY: Routledge.

Mir, A. (2009). Talibanisation of Pakistan: From 9/11 to 26/11. New York, NY: Pentagon Security International.

Mir, A. (2011, June 4). Who killed Syed Saleem Shahzad? Asia Times Online. [Online] Retrieved from http://content.time.com/time/world/article/0,8599,2074800,00.html

Mohiuddin, Y. N. (2006). Pakistan: a global studies handbook. ABC-CLIO. pp. 323-324.

Nizami, N.S. (2010). Population, labour force and employment. Ministry of Finance, Pakistan. 1-20. Retrieved from www.finance.gov.pk/survey/chapter_10/16_Population.pdf

Nordenstreng, K. (2001). Something to be done: transitional media monitoring. Transitional Broadcasting Studies Journal, Spring edition. [Online]. Retrieved from www.tbsjournal.com/ Archives/Spring01/nordenstreng.html

Pakistan Media Commission Report, May 13, 2013. (2013). http://mediacommissionreview.org/ article-19-19-a-of-the-constitution-of-pakistan/

Pakistan Press Foundation. (2007). Pakistan press freedom report. Retrieved from www.pakistanpressfoundation.org/userRAndDDetails.asp?uid $=248$

Peleg, S. (2007). Peace journalism through the lens of conflict theory: analysis and practice. In Shinar, D. \& Kempf, W. (Eds.), Peace journalism: the state of the art, (pp. 26-52). Germany: Regener.

Robie, D. (2014). Don't spoil my beautiful face. Media, mayhem and human rights in the Pacific. Auckland, New Zealand: Little Island Press.

Robie, D. (2004). Mekim Nius: South Pacific media, politics and education. Suva, Fiji: University of the South Pacific.

Ross, D. S. (2007). (De-)constructing conflict: a focused review of war and peace journalism. In D. Shinar, \& W. Kempf (Eds.), Peace journalism: the state of the art, (pp. 53-74). Germany: Regener.

Saleem, S. (2011, June 3). Mourning the silence. Dawn.com. [Online] Retrieved from www.dawn. com/news/633583/mourning-the-silence

Siebert, F., Peterson, T. \& Schramm, W. (1963). Four theories of the press. Urbana, Ill: University of Illinois Press

Tehranian, M. (2007). Preface. In D. Shinar \& W. Kempf (Eds.), Peace journalism: the state of the art, (pp. 7-8). Berlin: Regener

Tomalin, N. (1969, October 26). 'Stop the press I want to get on', London Sunday Times Magazine.

Walsh, D. (2011, June 13). Pakistan deadliest place to be a journalist, The Guardian. Retrieved from www.theguardian.com/media/2011/jun/13/pakistan-journalist-deasths-saleem-shahzad

Waraich, O. (2011, May 31). Pakistan journalist vanishes: Is the ISI involved? Time. [Online] Retrieved from http://content.time.com/time/world/article/0,8599,2074800,00.html

Dr Rukhsana Aslam is a journalist-turned-academic from Pakistan now living in New Zealand. She has her doctorate on the role of media in conflict with a focus on integrating peace journalism into the journalism curriculum, from the Auckland University of Technology (AUT), New Zealand. Before going to New Zealand in 2010, she was chair at the Centre for Media and Communication Studies, International Islamic University, Islamabad, Pakistan. At AUT, she has been affiliated with the Pacific Media Centre and was the recipient of Asia-New Zealand Foundation's Asian Journalism Fellowship Award in 2011. rukhsanaaslamkhan@hotmail.com

194 PACIFIC JOURNALISM REVIEW 21(1) 2015 